\title{
Analysis of Economic Efficiency and Influencing Factors of Commercial Banks based on Information Mining
}

\author{
Ruomei Xue \\ University of Illinois at Chicago, Chicago, United States \\ celine_xueruomei@126.com
}

\begin{abstract}
In the field of commercial banks with a huge amount of data, in order to achieve long-term development, we must attach great importance to the application of professional data processing technology. With the gradual opening of the financial market, foreign banks, especially international multinational banks with strong comprehensive strength, have entered the Chinese financial market one after another, which will undoubtedly bring great impact and challenges to Chinese commercial banks. Information mining, as a professional data processing technology, has been widely used in the field of huge data in recent years. The application of information mining in commercial banks can effectively improve the data processing ability and competitiveness of commercial banks. Strengthening the application of information mining is the inevitable choice for commercial banks to develop in the future. Based on information mining, this paper analyzes the economic efficiency and influencing factors of commercial banks. The efficiency of commercial banks is a core part of national commercial banks' pursuit of progress and competition in the global economy. This paper analyzes and studies the efficiency and influencing factors of national commercial banks.
\end{abstract}

Keywords: Information Mining; Commercial Banks; Economic Efficiency; Influencing Factors.

\section{Introduction}

In terms of business development, commercial banks have been unable to achieve full license operation. In addition, some local governments and state-owned enterprises explicitly prohibit opening accounts in urban commercial banks, and insurance companies are not allowed to buy subordinated bonds issued by urban commercial banks for financing. At present, the competition between Chinese commercial banks is becoming increasingly fierce. In the competition of commercial banks, information processing is an important part. The information processing ability of commercial banks directly affects the competitive level of commercial banks [1]. In the field of commercial banks with a huge amount of data, we must attach great importance to the application of professional data processing technology in order to achieve long-term development. With the gradual opening of the financial market, foreign banks, especially international multinational banks with strong comprehensive strength, have entered China's financial market, which will undoubtedly bring great impact and challenges to China's commercial banks. The competition among commercial banks will be more intense. If China's commercial banks want to develop and grow in the fierce market competition, they must improve their competitiveness, The efficiency of banks is the comprehensive embodiment of the competitiveness of commercial banks. Only efficient banks can be invincible in the fierce market competition [2-3]. Coupled with the disadvantages of small market share, weak competitiveness, weak profitability and low asset quality of commercial banks, it is difficult to resist large-scale risks; The weak technological innovation ability and the low level of staff education and skills also greatly reduce the operating efficiency of urban commercial banks and limit the healthy and sustainable development of urban commercial banks. At the beginning of the reform, commercial banks have indeed made many achievements through diversified strategic models. However, in the past three years, with the slowdown of macroeconomic growth and the deepening of interest rate marketization reform, commercial banks have seen a decline in the growth rate of profit margin and an increase in the growth rate of non-performing loan rate [4-5]. Whether commercial banks continue to implement the existing diversification strategy has aroused a lot of controversy in theory and practice. 
Information mining, as a professional data processing technology, has been widely used in the field of huge data in recent years. The application of information mining in commercial banks can effectively improve the data processing ability and competitiveness of commercial banks. Strengthening the application of information mining is the inevitable choice for future development of commercial banks [6]. As a more advanced performance of the bank informatization process, the information-based bank has made qualitative changes in the bank's customer service, business decision-making and strategy formulation through the centralization, integration, sharing and mining of information, that is, data. With the rapid development of information technology, banks have accumulated a great deal of data, and in recent years, they have set up data warehouses dedicated to business analysis. The idea of regarding data as an important asset has reached a consensus in Chinese banking industry.

\section{Looking Forward to and Exploring the Efficiency of Commercial Banks}

\subsection{Strengthen the Concept of Exploring the Efficiency of Commercial Banks}

Because the socialist market economy system has been established in general, China's property right composition, economies of scale, regulatory measures and financial regulation in some fields have greatly lagged behind the overseas excellent management model. As far as the existing research is concerned, the calculation of bank efficiency is mainly divided into financial index analysis method and production frontier analysis method. The financial index method mainly selects the relevant indicators reflecting the bank's operating conditions, such as using the return on assets, return on net assets and other indicators as the proxy variables to measure the bank's efficiency, while the production frontier analysis method is more to measure the effectiveness of bank resource allocation from the technical level [7]. The market competition situation is getting worse and worse. Compared with overseas banks, national commercial banks obviously lack strength. Therefore, we should strengthen the exploration of the efficiency of commercial banks, give full consideration to the real progress of national commercial banks, and rely on the internal and external situation of domestic commercial banks for a reasonable exploration and analysis. Because financial institutions are different from general production enterprises, they do not have tangible products, but the inflow and outflow of funds, there is a great controversy on the definition of input and output [8]. At present, the choice of input-output indicators of financial institutions abroad mainly includes production method, intermediary method, asset method, user cost method, value-added method and so on. According to the particularity of banking operation, this paper adopts the intermediary method, that is, rural commercial banks are regarded as intermediaries of capital financing, and their main function is to provide funds. At present, the competition in the banking industry is fierce. The rational allocation of limited resources, the integration of technical means and human capital have become the key to investigate the operation level of banks, as well as the key to the profitability and long-term development of banks.

\subsection{Improve the Interference Factors and Measurement Methods of National Commercial Banks}

Simply speaking, as far as the factors that interfere with the efficiency of commercial banks are concerned, the regulatory measures, the internal property rights structure of national commercial banks, the economic scale and other factors, such as external financial regulation and market competition, will interfere with the efficiency of national commercial banks to some extent. Risk control is the key link of commercial banks. The biggest challenges faced by banks are market risk, credit risk and operational risk. Through risk control, banks can effectively reduce losses while expanding the market, and ensure that the operation is within the controllable risk range. Because of this situation, the comparability of the efficiency of each department of the National Commercial Bank has not produced the flooding effect. In other words, the unity of the factors that disturb the efficiency of commercial banks and the measurement ways is a core point for the country to explore 
the efficiency of commercial banks now or in the future. On the basis of determining the production input elements and production output elements of each decision unit, the input and output elements of each unit are analyzed and measured, and then the effective production frontier is determined. The front surface is formed by piecewise linear combination of observation values of the decision-making unit with the best operating performance among the decision-making units, and it is a production possibility frontier convex to the origin. Analyze the credit risks faced by banks from the perspectives of customers, regions, industries and products, and analyze the interest rate risks and current risks by using analysis methods such as $\mathrm{I}=1$ analysis and ratio analysis, and provide various analysis and control tools so that all kinds of business risks can be monitored in time, provide information for risk identification, evaluation, monitoring and resolution, and support the transformation of risk management from qualitative management to quantitative management. Generally speaking, the framework structure of domestic commercial banks is the financial market situation in which finance exists and develops. Only through the further integration of factors and measurement methods that interfere with the efficiency of commercial banks can the research on the efficiency of national commercial banks be based on the difference of subjects, which makes the research of bank efficiency more mature.

\section{The Application of Information Mining in the Economic Efficiency of Commercial Banks and the Main Contents of Influencing Factors}

\subsection{Efficiency Evaluation of Commercial Banks}

Because financial institutions are different from general production enterprises, they do not have tangible products, but the inflow and outflow of funds, there are great disputes on the definition of input and output. At present, the choice of input-output indicators of financial institutions abroad mainly includes production method, intermediary method, asset method, user cost method, valueadded method and so on. According to the particularity of banking operation, this paper adopts information mining, that is, rural commercial banks are regarded as intermediaries of financing, and their main function is to provide funds. Customer loyalty is a comprehensive evaluation value based on the trust in the bank, transaction frequency, service effect, satisfaction and the possibility of continuing to accept the same bank service. In order to retain old customers and prevent the loss of customers, commercial banks must understand the needs of customers. According to the inputoriented model, the changes of technical efficiency value, pure technical efficiency value, scale efficiency value and scale return of six commercial banks are shown in Table 1.

Table 1. DEA efficiency values of commercial banks in 2021

\begin{tabular}{|c|c|c|c|c|}
\hline Bank & $\begin{array}{c}\text { Comprehensive technical } \\
\text { efficiency }\end{array}$ & $\begin{array}{c}\text { Pure technical } \\
\text { efficiency }\end{array}$ & $\begin{array}{c}\text { Scale } \\
\text { efficiency }\end{array}$ & $\begin{array}{c}\text { Returns to } \\
\text { scale }\end{array}$ \\
\hline Beijing Commercial Bank & 2 & 2 & 2 & Unchanged \\
\hline $\begin{array}{c}\text { Changshu Commercial } \\
\text { Bank }\end{array}$ & 2 & 2 & 2 & Unchanged \\
\hline $\begin{array}{c}\text { Guangzhou Commercial } \\
\text { Bank }\end{array}$ & 1.658 & 2 & 1.745 & Diminishing \\
\hline $\begin{array}{c}\text { Jiangsu Jiangyin } \\
\text { Commercial Bank }\end{array}$ & 1.562 & 1.698 & 1.4256 & Unchanged \\
\hline $\begin{array}{c}\text { Jiangsu Wujiang } \\
\text { Commercial Bank }\end{array}$ & 1.268 & 1.548 & 1.659 & Increasing \\
\hline
\end{tabular}

From the perspective of comprehensive efficiency, the comprehensive technical efficiency of Beijing Commercial Bank and Changshu commercial bank is 2. According to the definition, the two banks are at the forefront of production efficiency and are the optimal decision-making unit.

Second, from the perspective of pure technical efficiency, the pure technical efficiency value of Beijing Commercial Bank, Changshu commercial bank and Guangzhou commercial bank is 2 . 
According to the definition, the management level of these three banks is good, while the efficiency of other rural commercial banks is affected by the management level.

Third, from the perspective of returns to scale, Beijing Commercial Bank and Changshu commercial bank have seen a decline in returns to scale. The main reason is that their scale expansion speed exceeds the improvement speed of management level.

There is a significant positive correlation between the economic efficiency and loan quality of state-owned commercial banks, while the economic efficiency and loan quality of joint-stock commercial banks have not passed the significance test, which shows that the improvement of asset quality and loan quality plays an important role in improving the efficiency of state-owned banks in information mining, and its impact is greater than that of joint-stock commercial banks.

\subsection{Influencing Factors of Commercial Bank Efficiency}

According to the development characteristics of China's rural commercial banks based on information mining, this paper selects the following six aspects to investigate the factors that affect the efficiency of rural commercial banks:

(1) Bank size

From the perspective of economics, there is a point of maximizing economies of scale in any industry, and the efficiency shows a U-shaped trend of first rising and then falling with the expansion of scale. The scale of rural commercial banks can be estimated by total assets, total income, total deposits, etc. Considering the high correlation of these indicators, this paper selects total assets to measure the scale of rural commercial banks.

(2) Asset allocation

Asset allocation refers to the decision made by bank managers on the types, quantities and structural combinations of assets and liabilities they hold. This paper selects loan-to-deposit ratio to measure the efficiency of asset allocation. The higher the index value, the higher the efficiency of banks.

(3) Innovative ability

Debt business is the traditional business of commercial banks, and the development of intermediary business reflects the innovative ability of banks, and the operating income is selected to measure the innovative ability of banks.

(4) Management ability.

The asset expense ratio, that is, the total operating expenses, is used to measure the bank's management ability, and it is inferred that it has a negative impact on the efficiency of rural commercial banks.

In order to avoid multicollinearity and other problems, when choosing the input variables and output variables of the model, this paper refers to the predecessors' selection of frontier efficiency input and output indicators of commercial banks, and determines that net profit (pro) is the equation dependent variable, management expenses (adm) and total assets (ass) are input variables, and deposits (aep) and loans (Ion) are output variables. As shown in Table 2.

According to the current development level of influencing factors of bank efficiency, the business scope of some early-established rural commercial banks is widely distributed, not limited to a certain urban area, while the business scope of some newly-established banks is still concentrated in a certain urban area. This shows that the economic efficiency of state-owned banks is greater than that of jointstock banks due to the reduction of management costs of information mining. It just shows that stateowned banks only pay attention to increasing investment in manpower without considering costs, especially the increase of fixed assets. In addition, the huge redundant staff and workers, various management levels and institutions and backward management mechanism lead to their large scale of operation, which leads to more expenditure on management costs of information mining. 
Table 2. Setting of economic efficiency measurement indicators of commercial banks

\begin{tabular}{|c|c|c|c|}
\hline $\begin{array}{c}\text { Variable } \\
\text { classification }\end{array}$ & Variable name & $\begin{array}{c}\text { Variable } \\
\text { code }\end{array}$ & Explaining variables \\
\hline $\begin{array}{c}\text { Be interpreted } \\
\text { and changed }\end{array}$ & Net profit & pro & $\begin{array}{c}\text { The difference between the total annual profit and income tax } \\
\text { of city commercial banks is an index to measure the operating } \\
\text { efficiency of city commercial banks. }\end{array}$ \\
\hline & $\begin{array}{c}\text { Management } \\
\text { cost }\end{array}$ & adm & $\begin{array}{c}\text { Expenses incurred by city commercial banks for organizing } \\
\text { and managing business activities }\end{array}$ \\
\cline { 2 - 5 } & Total assets & ass & $\begin{array}{c}\text { The sum of all assets owned and controlled by city } \\
\text { commercial banks that can bring economic benefits to them is } \\
\text { also a reference index to measure the scale of city commercial } \\
\text { banks. }\end{array}$ \\
\hline Output variable & Leposit & dep & $\begin{array}{c}\text { The main source of credit funds of city commercial banks } \\
\text { refers to the monetary funds that enterprises or individuals } \\
\text { retain ownership absorbed by city commercial banks. }\end{array}$ \\
\cline { 2 - 4 } & lon & $\begin{array}{c}\text { Monetary fund's lent by city commercial banks according to } \\
\text { certain interest rates and conditions such as repayment are a } \\
\text { form of credit activities of city commercial banks and one of } \\
\text { the important sources of profits for city commercial banks. }\end{array}$ \\
\hline
\end{tabular}

\section{Conclusion}

The operation of rural commercial banks is generally good. The reason for the low efficiency of non-cutting-edge rural commercial banks may be the lack of management level or the failure to achieve economies of scale. Compared with the best banks in the sample, some banks' returns to scale have been in a decreasing stage. While optimizing the ownership structure and proportion, urban commercial banks can also realize the combination of "attracting capital", "attracting intelligence" and "introducing technology". For example, in the management level, absorb the excellent talents brought by the new shareholders, and use the advanced management concept and superior technical conditions brought by the new shareholders in the governance mechanism. The innovation ability and management ability of commercial banks are the main factors affecting their efficiency, while the asset scale, deposit loan ratio, equity concentration and business scope have no significant impact on the efficiency of rural commercial banks. Information mining plays an increasingly important role in the economic efficiency and influencing factors of commercial banks. The application of this technology can effectively improve the competitiveness of commercial banks. With the deepening of China's market economic system reform, the competition between commercial banks is becoming increasingly fierce. Under this background, strengthening the research of data mining is of great significance to improve the competitiveness of commercial banks.

\section{References}

[1] Pan X, Zhang J, Li C, et al. Analysis of China's regional wind power generation efficiency and its influencing factors [J]. Energy \& Environment, 2019, 30(2):254-271.

[2] Alalwan A A, Dwivedi Y K, Rana N P. Factors influencing adoption of mobile banking by Jordanian bank customers: Extending UTAUT2 with trust [J]. International Journal of Information Management, 2017, 37(3):99-110.

[3] Jaabi S, Fatty A. Measuring Efficiency of Commercial Banks in The Gambia[J]. The Social Science Journal, 2018, 5(11):631-651.

[4] Sh A, Msd B, Rs B. Assessing energy efficiency of Indian paper industry and influencing factors: A slackbased firm-level analysis[J]. Energy Economics, 2019, 81:454-464.

[5] Gao X, Chen J, Huai N. Mining heterogeneous information networks [J]. Information Processing \& Management, 2019, 55(3): 844-857. 
[6] Lee H, Choi K, Yoo D, et al. Recommending valuable ideas in an open innovation community A text mining approach to information overload problem[J]. Industrial management \& data systems, 2018, 118 (4): 683-699.

[7] Mirtsch M, J Kinne, Blind K. Exploring the Adoption of the International Information Security Management System Standard ISO/IEC 27001: A Web Mining-Based Analysis[J]. IEEE Transactions on Engineering Management, 2020, PP (99):1-14.

[8] Martin N, Fischer D A, Kerpedzhiev G D, et al. Opportunities and Challenges for Process Mining in Organizations: Results of a Delphi Study[J]. Business \& Information Systems Engineering, 2021, 63 (10): 1-17. 